\title{
ANTITRUST RESTRICTIONS ON TRADE SECRET LICENSING: A LEGAL REVIEW AND ECONOMIC ANALYSIS
}

\section{INTRODUCTION}

Laissez-faire economics postulates that in a free market system in which there are many producers struggling independently to satisfy the demands of innumerable consumers, an invisible hand guides the producers to produce the goods and services that consumers desire most in the greatest quantities and at the lowest cost. In this ideal economic state postulated by Adam Smith, the determination of what to produce, how much, and for whom, is the result of the aggregation of an infinite number of miniscule purchasing agreements between competing producers and consumers. The result of perfect competition is an allocation of scarce productive resources such that no possible reallocation could increase consumer welfare.

In the real world, however, a lack of complete information about consumers' demands and producers' products, and limitations on the mobility of productive resources, prevent attainment of this economic utopia. Furthermore, the small number and large size of producers and consumers, respectively, as well as differentiation of products and productive resources, enable individual purchasing contracts to affect the allocation of resources. Thus, there may be a conflict between the goals of contracting parties seeking to maximize their own welfare and the goals of social welfare economics. For example, a contract between a firm that possesses secret information about an industrial process and a firm that would like to obtain and use that information may have an effect on the allocation of productive resources. That effect may be to induce greater expenditure for the generation of useful industrial information, or it may simply be to increase the wealth of the firms possessing that information without any collateral benefit to society.

One purpose of antitrust law is to minimize the conflict between the welfare maximizing goals of individual firms and those of society as a whole by regulating the terms of contracts. A trade secret license is one type of contract that is subject to antitrust regulation. This note will survey the legal treatment that has been accorded various trade secret license terms under the antitrust laws (Part IV), and then will analyze that legal treatment in view of 
economic analyses that have been applied to antitrust regulation of patent licensing agreements (Part V). As a background to these inquiries, the nature of trade secret protection will be discussed in Part II, and trade secret licensing agreements will be described in Part III.

II

\section{Legal Protection for Trade Secrets}

To understand trade secret licensing and to analyze the antitrust limitations that have been placed on restrictive clauses in licensing agreements, it is helpful to examine the nature of the legal rights being licensed.

A trade secret is a legal interest in business or technical information, which, like other intangible property rights, entitles the holder to possession and use of the information. Trade secrets are often equated with know-how, which consists of everything that is required to start up a business excluding labor and tangible capital. ${ }^{1}$ Unlike federally protected intellectual property, which includes patents, trademarks, and copyrights, trade secrets are not represented by any document of registration. Although recognized by federal law, ${ }^{2}$ trade secrets are protected only by state law. Most states recognize the definition of a trade secret provided by comment b of the Restatement (Second) of Torts:

A trade secret may consist of any formula, pattern, device or compilation of information which is used in one's business, and which gives him an opportunity to obtain an advantage over competitors who do not know or use it. It may be a formula for a chemical compound, a process of manufacturing, treating or preserving materials, a pattern for a machine or other device or a list of customers . . . . ${ }^{3}$

A similar definition was approved by the drafters of the Uniform Trade Secrets Act:

information, including a formula, pattern, compilation, program, device, method, technique, or process, that (i) derives independent economic value, actual or potential, from not being generally known to, and not being readily ascertainable by proper means by, other persons who can obtain economic value from its disclosure or use, and (ii) is the subject of efforts that are reasonable under the circumstances to maintain its secrecy. 4

A few aspects of trade secret law are worthy of elaboration. The basis for protecting a trade secret is the natural or common law right to the fruits of

1. Macdonald, Know-how Licensing and the Anti-trust Laws, 62 Mich. L. Rev. 351, 355 (1964).

2. Bankruptcy Code, 11 U.S.C. $\$ 107$ (b)(1) (1982); Federal Trade Commission Act, 15 U.S.C. $\S 46(\mathrm{f})$ (1982); Freedom of Information Act, 5 U.S.C. $\$ 552$ (b)(4) (1982); 15 U.S.C. § 78x(b) (1982); 18 U.S.C. \$ 1905 (1982) (criminalizing federal employees' disclosure of trade secrets); see Oppenheim, The Patent-Antitrust Spectrum of Patent and Know-how License Limitations: Accommodation? Conflict? or Antitrust Supremacy?, 15 IDEA 1, 22 (1971).

3. See 12 R. Milgrim, Business Organizations: Milgrim on Trade Secrets $\$ 2.01$, at $2-3$ to 2-13 (1986).

4. The Uniform Trade Secrets Act (1979) may be found in 12B R. Milgrim, Business Organizations: Milgrim on Trade Secrets, at appendix A (1986). For a list of states that have adopted the Act with or without modifications, see $i d$. at appendix AA. 
one's labor. ${ }^{5}$ The property right subsists only as long as the information sought to be protected remains secret. ${ }^{6}$ Secrecy need not be absolute, and, as indicated by the Uniform Act definition, depends on the owner's efforts to keep his proprietary information confidential. Although there is no explicit novelty prerequisite to protection of a trade secret, secrecy implies a minimum degree of novelty. Information that is generally known in the trade cannot be secret. The value of a trade secret may be measured by the investment of time, labor, and money expended to create the know-how and prevent its revelation to competitors. ${ }^{7}$

Trade secrets or know-how are distinguishable from patents in several respects. First, the scope of material covered by trade secret law is broader than that which may be patented. For example, trade secret law would likely protect the data obtained by repeated routine experiments requiring significant expenditure of time and effort. Regardless of the abilities of the data to determine the most efficient method of carrying out an industrial process or business practice, such data would probably not satisfy the novelty and non-obviousness requirements of the patent law, although such knowhow can form the backbone and structure of a business. ${ }^{8}$

The second and most important difference between trade secret and patent law is the greater degree of protection offered by patent law. A patent is a legal monopoly against the entire world, ${ }^{9}$ while a trade secret confers rights only against those with whom the owner has contracted, expressly or by implication, or those who obtain the secret by improper means. ${ }^{10}$ An example of improper means of discovery of a competitor's secret process would be to fly over and take a photograph of his manufacturing plant while it is under construction." Thus, trade secret law, unlike a patent, "cannot be used as an offensive weapon" to interfere with the business operations of others who obtain or use the trade secret without incurring a contractual obligation to the owner or engaging in tortious acts. ${ }^{12}$ Discovery of a trade secret by

5. R. Ellis, Patent Assignments and Licenses Including Trade Secrets $\$ 3$, at 2 (2d ed. 1943); see Fowle v. Park, 131 U.S. 88 (1889).

6. R. ElLIS, supra note 5 , at $\S 2$, at 2.

7. See id. $\$ 10$, at 16; Arnold, Basic Considerations in Licensing, in ABA Section of Patent, Trademark and Copyricht Law, Recent Developments in Licensing 13 (1981) [hereinafter ABA RECENT DEVElopments].

8. See, e.g., Choisser Research Corp. v. Electronic Vision Corp., 173 U.S.P.Q. 234, 235 (Cal. Super. Ct., San Diego Co. 1972) (a trade secret may consist of production techniques or know-how that even a good mechanic could develop).

9. The patent law rewards inventors with a 17 -year exclusive right, enforceable in federal court, to make, use, and sell the patented invention, 35 U.S.C. $\$ 271$ (1982), in return for disclosure to the public of a description of the invention and of the manner and process of using it which enables any person skilled in the art to make and use it, 35 U.S.C. $\$ 112$ (1982); Kewanee Oil Co. v. Bicron Corp., 416 U.S. $470,480-81$ (1974).

10. R. Ellis, supra note 5, at § 3, at 3; Allen-Qualley Co. v. Shellmar Prod. Co., 31 F.2d 293, 296 (D. Ill.), affd, 36 F.2d 263 (7th Cir. 1929).

11. E.I. duPont deNemours \& Co. v. Christopher, 431 F.2d 1012 (5th Cir.), cert. denied, 400 U.S. $1024(1970)$.

12. Macdonald, supra note 1 , at 354 . 
independent invention, accidental disclosure, or reverse engineering is not actionable. ${ }^{13}$

The purpose of trade secret law is to maintain standards of commercial ethics and to encourage invention. The Supreme Court held in Kewanee Oil Co. v. Bicron Corp. ${ }^{14}$ that Congress' power under the Constitution "to promote the Progress of Science and the useful Arts" 15 is not exclusive. States may act to protect inventions as long as state laws do not conflict with the operation and purpose of the federal patent law. ${ }^{16}$

Patent and trade secret protection are mutually exclusive. Under the statutory bar of 35 United States Code section 102(b), ${ }^{17}$ an inventor must apply for a patent within one year of reducing his invention to practice for commercial advantage; otherwise he forfeits patent protection. If a patent issues, the information disclosed in the specification is public and no longer protectable by trade secret law. Until a patent issues, or if the application is rejected, however, the Patent Office is obligated not to disclose the subject matter, ${ }^{18}$ and the applicant is still entitled to trade secret protection, if the information has not otherwise been disclosed.

Recently there has been increased interest in state trade secret law as a form of intellectual property protection for computer software and biotechnological inventions due to the inadequacy or disadvantages of federal copyright and patent law for these types of innovation. ${ }^{19}$ Patent protection is often legally unavailable for computer software because of the Supreme Court's position that a mathematical algorithm, apart from any patentable industrial process, is not patentable. ${ }^{20}$ The fact that copyright protects only the expression of ideas and not the ideas themselves suggests that a copyright may be inadequate protection for computer software. A copyright cannot be used to prevent decompiling, disassembling, or reverse-compiling machinereadable to human-readable code in order to discover the functional aspects of the software, which represent its real value. ${ }^{21}$ The ideas that are expressed

13. Kewanee Oil Co. v. Bicron Corp., 416 U.S. 470, 476 (1974). Reverse engineering means starting with the lawfully acquired known product and working backward to find the method by which it was developed. Commissioners' Comment to the Uniform Trade Secrets Act, in 12B R. Milgrim, supra note 4 , at A-7.

14. 416 U.S. 470 (1974).

15. U.S. Const. art. I, $\$ 8$.

16. Kewanee Oil Co., 416 U.S. at 479.

17. 35 U.S.C. $\S 102$ (b) (1982).

18. Id. $\S 122$.

19. Dratler, Trade Secret Law: An Impediment to Trade in Computer Software, 1 Santa Clara Computer \& High TeCh. L.J. 27, 42 (1985); Karny, Biotechnology Licensing, 8 Licensing L. \& Bus. ReP. 1,5 (1985).

20. Gottschalk v. Benson, 409 U.S. 63 (1972) (algorithm for converting decimal to binary code); Parker v. Flook, 437 U.S. 584 (1978) (method for calculating an alarm limit); $c f$. Diamond v. Diehr, 450 U.S. 175 (1981) (method for molding rubber which used Arrhenius equation).

21. Dratler, supra note 19, at 38; Harris, A Market-Oriented Approach to the Use of Trade Secret or Copyright Protection (or Both?) for Software, 25 Jurimetrics J. 147, 157, 169 (1985). 
in a computer program may be protected as trade secrets, however, and the above processes may be prohibited in a software license. ${ }^{22}$

Trade secret protection may be more desirable than patent protection for biotechnological inventions because deposit of a culture of an organism that constitutes part of a patent claim may be necessary to satisfy the enabling disclosure requirement of 35 United States Code section 112.23 If such deposit in a recognized culture collection is required, the culture must be made available to the public without restriction for at least thirty years after the patent issues. ${ }^{24}$ When the biotechnologist deposits a microorganism that he has invented, he has relinquished control of "the factory instead of just the plans for constructing it."25 The right to possess the microorganism is significantly more valuable than the corresponding intangible intellectual property rights; hence the owner may prefer to rely on trade secret law rather than to obtain a patent.

Having examined the nature of trade secret rights and the comparative protection provided by the patent law, this note proceeds to a discussion of licensing.

\section{III}

\section{Introduction to Trade Secret Licensing}

The owner of a trade secret has the exclusive right to use it in his business as long as the information remains secret and no one else discovers it independently by legitimate means. The owner's disclosure of his trade secret is a de facto license to use the information, since apart from secrecy, the owner has no exclusive rights. Therefore when the trade secret owner licenses his trade secret, the consideration paid by the trade secret licensee is really in exchange for disclosure, not for use, as in the case of a patent license. ${ }^{26}$ In contrast to the patent licensee, the trade secret licensee is often uncertain of the usefulness and value of the licensed information until after his contractual obligation to pay consideration has begun. Since trade secret law will not protect whatever enters the public domain with sale of the product, a potential licensee must bargain for disclosure knowing that third

22. Dratler, supra note 19, at 48. Trade secret protection for computer software is not without uncertainty, however. First, compliance with the copyright law requirement that a copy of the protected work be deposited in the Library of Congress, 17 U.S.C. $\$ 407$ (a) (1982), may be deemed a public disclosure, negating secrecy. In addition, placing a copyright notice on licensed copies of the software may constitute an implied admission that the software has been published. Second, absent an enforceable contract prohibiting a licensee from analyzing licensed software, trade secret law would not protect against reverse engineering. Finally, section 301 of the 1976 Copyright Act may preempt state law protection for computer software. 17 U.S.C. $\S 301$ (a) (1982). See Dratler, supra note 19, at 38, 45; Harris, supra note 21 , at 157 .

23. 35 U.S.C. $\$ 112$ (1982).

24. F. Beier, R. Crespi \& J. Straus, Biotechnology and Patent Protection, An INTERNATIONAL REVIEW 57-58 (1985).

25. Karny, supra note 19 , at 2.

26. Milgrim, Sears to Lear to Painton: Of Whales and Other Matters, 46 N.Y.U.L. REv. 17, 30 (1971). 
parties may discover the trade secret and have the advantage of royalty-free use. ${ }^{27}$

Like a patent license, a trade secret license confers no affirmative rights; a license is merely a withholding of the licensor's right to bring action against the licensee under either state trade secret law or federal patent law, as the case may be. ${ }^{28}$ Just as the patent licensor is permitted to relinquish only part of his right to bring an infringement action against anyone who makes, uses, or sells the patented invention, ${ }^{29}$ the trade secret licensor may relinquish only part of his right under state law to bring action for misappropriation, use, or disclosure of the secret. Furthermore, the trade secret licensor may extract from his licensee, as part of the consideration for the license, restrictions on the right to use the information disclosed. The aim of this note is to analyze the antitrust law limitations on this contractual right to bargain for and agree on trade secret license restrictions.

The following is a simple example of a trade secret license:

Licensor hereby agrees to furnish to licensee during the term hereof engineering and manufacturing services and techniques, which include specifications, drawings, equipment designs and circuitry, cost breakdowns, operations descriptions and other information necessary to enable licensee to manufacture licensor's products covered by this agreement. ${ }^{30}$

As the above example shows, the disclosure to the licensee may take various forms. Often a license agreement transfers other tangible and intangible property in addition to the trade secret, such as personnel, equipment, patents, and trademarks. The substance of licensing agreements depends on the characteristics of the particular technology being licensed and the needs of the business which exploits it. ${ }^{31}$

The proprietor of valuable technology will license another firm to exploit his technology when the proprietor is unable or unwilling to enter a new market himself. A firm or educational institution engaged in research may lack the capital to implement its research and must license others in order to make a profit. Even a firm that would be capable of exploiting its newly developed technology might not want to incur the risk of making the capital expenditure necessary to produce and market the good or service that it developed. For the firm wishing to enter a foreign market, licensing may be the only feasible option; tariffs and quotas may render exportation uneconomical, and, aside from a prohibitively large capital outlay, there may be foreign legal restrictions to direct foreign investment in manufacturing facilities. ${ }^{32}$ Licensing gives the licensor the opportunity to derive additional income from intangible property through royalties and gives the licensee the

27. Id.

28. Arnold, supra note 7, at 19-20.

29. 35 U.S.C. 8271 (1982); see Arnold, supra note 7, at 19-20.

30. Painton \& Co. v. Bourns, Inc., 442 F.2d 216, 219 (2d Cir. 1971).

31. Kiley, Biotechnology: Evolution of a New Venture and its Licensing Strategy, in A.B.A. RECENT Developments, supra note 7, at 106.

32. A.B.A. Antitrust Section, Monograph No. 6, U.S. Antitrust law in International Patent and Know-how Licensing 2 (1981) [hereinafter ABA Antitrust Section Monograph]. 
opportunity to use its existing distribution system to market the products of a technology to which it would not otherwise have access. ${ }^{33}$

The decision to license technology is influenced by the owner's market structure; the factors that he considers include the nature, number, and geographic distribution of his competitors; the number of different applications for the technology; the positions in the market structure occupied by the owner and his potential licensee; and any perceived trends in that market structure. ${ }^{34}$ Other important considerations are the capital and labor needed for starting up; the requirements for distribution and sales of the products of the licensed technology; and the nature of the technology, since it affects whether local trade secret law will protect the owner's rights. ${ }^{35}$

Before the Supreme Court decisions in Kewanee Oil and Aronson $v$. Quick Point Pencil Co., ${ }^{36}$ the validity of licenses enforceable under state trade secret law had been uncertain with regard to the exclusivity of congressional power and the supremacy of federal patent law. This uncertainty is evidenced by a federal district court decision invalidating a trade secret licensing agreement in Painton $\mathcal{E}^{\circ}$ Co. $v$. Bourns, Inc., on grounds that patent law policy prohibited contracts for compensation for use of secret ideas that had not been submitted to the patent office. ${ }^{37}$ The Kewanee decision, however, confirmed the court of appeals reversal in Painton $\mathcal{E}^{2} \mathrm{Co}$. $v$. Bourns, Inc. ${ }^{38}$ Although federal law may require that all ideas in general circulation be dedicated to the common good, ${ }^{39}$ it does not require that all ideas be placed in general circulation. 40 Rather, the trade secret owner "may keep his invention secret and reap its fruits indefinitely."41

In Aronson, the Supreme Court further clarified the validity of licenses enforceable under state trade secret law. It enforced the royalty obligation of a licensee who agreed to pay a patent applicant a reduced percentage of sales if the application was denied. ${ }^{42}$ This decision stands in contrast to previous holdings that a patentee may not require payment of royalties beyond the term of a patent, ${ }^{43}$ nor after a patent has been held invalid. ${ }^{44}$ The Aronson

33. Id. at 1 .

34. Arnold, supra note 7 , at 6 .

35. Id. For a discussion of the special considerations of trade secret licensors in the computer software and biotechnology industries, see Harris, supra note 21, at 150-52; Karny, supra note 19, at $1-2$.

36. 440 U.S. 257 (1979). 20.

37. Painton \& Co. v. Bourns, Inc., 309 F. Supp. 271 (S.D.N.Y. 1970); Milgrim, supra note 26, at

38. 442 F.2d 216 (2d Cir. 1971).

39. Lear, Inc. v. Adkins, 395 U.S. 653, 668 (1969).

40. Painton E Co., 442 F.2d at 225.

41. Id. (citing United States v. Dubilier Condenser Corp., 289 U.S. 178, dec. amended, 289 U.S. 706 (1933)); of. Lear, Inc., 395 U.S. at 677 (Black, J., joined by Burger, C.J., and Douglas, J., dissenting, wrote, "[N]o state has the right to authorize any kind of monopoly on what is claimed to be a new invention....").

42. Aronson v. Quick Point Pencil Co., 440 U.S. 257, 259 (1979). The licensor agreed to a 5\% royalty if a patent was issued and a $2.5 \%$ royalty if no patent was issued.

43. Brulotte v. Thys Co., 379 U.S. 29 (1964).

44. Lear, Inc. v. Adkins, 395 U.S. 653, 672 (1969) (suspending licensee's royalty obligation 
Court held that the licensee's royalty obligation was independent of federal law. Even though the licensed design could be easily copied and the licensee's competitors were free of any royalty obligation, requiring the licensee to pay royalties was not inconsistent with the patent law. ${ }^{45}$

Having examined what trade secret owners seek to achieve through licensing and determined that enforcement of trade secret license agreements is not unconstitutional nor contrary to federal law, this note now proceeds to a discussion of several antitrust challenges to various trade secret license provisions.

\section{IV}

\section{Antitrust Validity of Trade Secret License Restrictions}

The owner of secret technology has the right to exploit that technology and maintain its secrecy indefinitely without incurring liability under the antitrust laws. "[A] firm may normally keep its innovations secret from its rivals as long as it wishes, forcing them to catch up on the strength of their own efforts after the new product is introduced ...."46 Even an arbitrary and discriminatory refusal to license proprietary technology would likely not violate section 2 of the Sherman Act. ${ }^{47}$ When the owner of proprietary information does enter an agreement to disclose that information in exchange for consideration, the parties to the license are bound by the provisions of section 1 of the Sherman Act: "Every contract, combination in the form of trust or otherwise, or conspiracy, in restraint of trade or commerce among the several States, or with foreign nations, is declared to be illegal ..."48 Often, however, the trade secret owner or his potential licensee is unwilling to enter a license agreement unless it provides for certain restrictions. Such restrictions include limitations on the territories within which the licensor or licensee is permitted to use the licensed know-how, requirements that the licensee purchase materials or services from the licensor, restriction on price and output, requirements that the licensee disclose any know-how it develops while using the licensed process, and restrictions on the technical fields for which the licensee may use the licensed trade secret. The following discussion will focus on the first three limitations listed above, since they have received the greatest judicial attention. ${ }^{49}$ The discussion will be preceded,

during the time patent validity is being challenged in court).

45. Aronson, 440 U.S. at 263.

46. Berkey Photo, Inc. v. Eastman Kodak Co., 603 F.2d 263, 281 (2d Cir. 1979), cert. denied, 444 U.S. 1093 (1980) (citing Kewanee Oil v. Bicron Corp., 416 U.S. 470 (1974)).

47. Mannington Mills, Inc. v. Congoleum Indus., Inc., 610 F.2d 1059, 1072 (3d Cir. 1979). The Sherman Act, 15 U.S.C. $\S 2$ (1982), provides, "[E]very person who shall monopolize, or attempt to monopolize, or combine or conspire with any other person or persons, to monopolize any part of the trade or commerce among the several States, or with foreign nations shall be deemed guilty of a felony ...."

48. 15 U.S.C. $\& 1$ (1982).

49. Kirkpatrick \& Mahinka, Antitrust and the International Licensing of Trade Secrets and Know-How: A Need for Guidelines, 9 L. \& PoL'y INT'L Bus. 725, 738 (1977). These authors conjecture that price, output, and field-of-use restrictions would be permissible in circumstances where territorial 
however, by an examination of the antitrust limitations placed on the term during which the trade secret licensor may demand royalties from his licensee.

\section{A. Royalty Term}

The issue of the permissible royalty term under a trade secret license has arisen in two distinct contexts. Where the subject matter of a license agreement is protected purely by trade secret law, challenges to the agreement are often brought by the licensee after the trade secret has become available to the licensee's competitors. Where a license agreement pertains to a mixture of patent and trade secret protected information, the licensor often claims that know-how supports the royalty obligation after the patents have expired or have been held invalid.

The validity of the royalty term of a license involving only trade secrets is purely a matter of contract law; any term freely agreed upon by the licensor and licensee is enforceable. ${ }^{50}$ If the parties fail to stipulate when a royalty obligation should terminate, the court will not imply such a term but will enforce the obligation as long as the licensee uses the trade secret. ${ }^{51}$ WarnerLambert v. John F. Reynolds, Inc. ${ }^{52}$ is the classic case establishing the law in this area. The inventor of Listerine antiseptic conveyed the secret formula to Warner-Lambert's predecessor in interest in exchange for a sales royalty obligation. After seventy-five years of operating under the contract, WarnerLambert sought a declaratory judgment dissolving its royalty obligation on grounds that the formula was no longer secret. The court denied relief holding that, in contrast to the case of a royalty term under a patent license, there was no public policy that prevented enforcement of a royalty obligation after public disclosure of the licensed trade secret. ${ }^{53}$ Warner-Lambert acquired the secret formula and commercially exploited it subject to the risk of disclosure. The inventor was entitled to receive royalties for as long as Warner-Lambert used the formula. 54

After the Supreme Court decided Lear and before its decision in Aronson, at least one court refused to apply the Warner-Lambert rule, reasoning that a trade secret royalty obligation must end with public disclosure, just as a patent royalty may not extend beyond invalidity. ${ }^{55}$ In view of the assumption that

restraints would not violate the antitrust laws, since the former are less complete restraints than a territorial allocation of markets.

50. Pitney Bowes, Inc. v. Mestre, 517 F. Supp. 52, 62-63 (S.D. Fla. 1981), affd, 701 F.2d 1365 (1 1 th Cir.), cert. denied, 464 U.S. 893 (1983); Christiansen, Royalties After Life, (part 2), 5 Licensing L. \& Bus. Rep. 49, 54 (1983).

51. Warner-Lambert Pharmaceutical Co. v. John J. Reynolds, Inc., 178 F. Supp. 655 (S.D.N.Y. 1955), aff'd per curiam, 280 F.2d 197 (2d Cir. 1960); Laff v. John O. Butler Co., 64 Ill. App. 3d 603, 381 N.E.2d 423 (1st Dist. 1978), cert. denied, 444 U.S. 844 (1979); Christiansen, supra note 50, at 5152; Niegowski \& McKie, Significant Recent Case Law Affecting Trade Secret/Know-how Licensing, in A.B.A.

Recent Developments, supra note 7, at 50-51.

52. 178 F. Supp. at 655 .

53. Id. at 665 .

54. Id. at 662; see also Laff v. John O. Butler Co., 64 Ill. App. 3d at 617, 381 N.E.2d at 433.

55. Choisser Research Corp. v. Electronic Vision Corp., 173 U.S.P.Q. 234 (Cal. Super. Ct., San Diego Co. 1972); see Christiansen, supra note 50, at 53. 
disclosure is what the trade secret licensee has really bargained for, however, the royalty contract should be enforced. ${ }^{56}$ The parties to a licensing contract agree on a royalty on the basis of the revenue that they expect to be produced through use of the trade secret during the period of its commercial viability. ${ }^{57}$ The judiciary should not remedy mistakes in the parties' estimations.

Although a royalty obligation is enforceable beyond the time of public disclosure without any antitrust implications (if such disclosure is not due to the fault of either the licensor or the licensee), a licensor may violate section 1 of the Sherman Act by attempting to prevent his licensee from using the trade secret after expiration of the license term when the secret has become publicly known. ${ }^{58}$ To enjoin the use of information freely available to one's competitors would be to enforce a contract in restraint of trade.

If the subject matter of a license is protected by both patents and trade secrets and the agreement does not clearly differentiate between the two by providing a separate royalty for each, then there is no enforceable royalty for the trade secrets after invalidity or expiration of the patents.59 A hybrid license cannot be used to extend the patent monopoly in contradiction of Brulotte. ${ }^{60}$ This rule preserves the licensee's incentive to challenge the validity of licensed patents upheld in Lear. ${ }^{61}$

Extention of the royalty obligation beyond the time of public disclosure of the trade secret is a form of tying ${ }^{62}$ because the licensor is extracting more consideration than merely a royalty payment during the life of the secret. But more serious and complicated antitrust controversies have arisen concerning product tying arrangements and territorial restrictions than those involving the royalty term of a trade secret license.

\section{B. Territorial Restrictions}

A trade secret license may include territorial restrictions. For example the licensee may agree to use the licensed know-how only in his home territory and not to export products of the licensed technology or to export only to certain assigned territories. Similarly, the licensor may agree not to operate

56. Milgrim, supra note 26 .

57. Christiansen, supra note 50, at 56-57.

58. CVD, Inc. v. Raytheon Co., 1981-2 Trade Cases (CCH) ๆ 64,424 (D. Mass. 1981); Shell v. Atco Corp., 207 U.S.P.Q. 126 (Ill. Cir. Ct. 1980); Arnold, supra note 7, at 21.

59. Span-Deck, Inc. v. Fab-Con, Inc., 677 F.2d 1237, 1247 (8th Cir.), cert. denied, 459 U.S. 981 (1982); St. Regis Paper Co. v. Royal Indus., 552 F.2d 309, 315, cert. denied, 434 U.S. 996 (1977); Veltman v. Norton Simon, Inc., 425 F. Supp. 774, 776 (S.D.N.Y. 1977); Christiansen, supra note 50, at 55; Niegowski \& McKie, supra note 51, at 48-50; O'Reilly \& Pula, Level Royalties in Hybrid Package Licenses, 7 Licensing L. \& Bus. Rep. 183, 188 (1984). Cf. Chromalloy American Corp. v. Fischmann, 716 F.2d 683, 686 (9th Cir. 1983); Robintech, Inc. v. Chemidus Wavin, Ltd., 628 F.2d 142, 149 (D.C. Cir. 1980) (both awarding know-how royalties under a hybrid license); Henderson, Recent Developments in United States Licensing Law, in A.B.A. Recent DeVelopments, supra note 7, at 105.

60. Brulotte v. Thys Co., 379 U.S. 29 (1964) (invalidating a contract to pay royalties for use of a patented machine beyond the term of the patent). See Veltman, $425 \mathrm{~F}$. Supp. at 775.

61. Lear, Inc. v. Adkins, 395 U.S. 653 (1969) (invalidating licensee estoppel); Timely Prod. v. Costanzo, 465 F. Supp. 91, 96 (D. Conn. 1979); Niegowski \& McKie, supra note 51, at 47; O'Reilly \& Pula, supra note 59, at 188 .

62. Brulotte, 379 U.S. at 33. 
in the licensee's territory and not to sell in territories reserved for his licensees. Modern territorial restrictions in patent and trade secret licenses are most often on a global scale, assigning one or more countries to each party exclusively.

Patent licensing creates a de facto allocation of territories similar to that exemplified by the above trade secret license restrictions but without the necessity of an express agreement. When a United States firm holding both United States and foreign patents grants exclusive licenses of its foreign patents without licensing its United States patents, the arrangement has the same effect as requiring his licensees to agree not to export to either the United States or to countries where the licensor has granted other exclusive licenses. ${ }^{63}$ This automatic territorial division of markets is a result of the fact that patent rights, and therefore patent licenses, are co-extensive with the territory of the sovereign that granted the patent. ${ }^{64}$ Patent laws have no extraterritorial effect. ${ }^{65}$ The ability to restrict competition by dividing markets is inherent in the structure of patent law. ${ }^{66}$

The same antitrust analysis has been applied regardless of the form of the agreement, whether an exclusive patent license, or a trade secret, or hybrid license containing explicit territorial restrictions. ${ }^{67}$ A territorial restriction in a trade secret license is valid if:

(1) the subject matter of the license is well defined, secret, and of substantial commercial value;

(2) the restriction does not affect products unrelated to the use of the licensed know-how;

(3) the period of the restriction is limited to the period required for independent development of the licensed know-how; and

(4) the licensor and licensee were not competitors in any market for any product affected by the license. ${ }^{68}$

63. Stern, The Antitrust Status of Territorial Limitations in International Licensing, 14 IDEA 580,582 (1971). For a criticism of the view that these situations are legally equivalent, see Forman, Another View of the Antitrust Status of Territorial Limitations in International Licensing, 15 IDEA 27, 29 (1971).

64. Mannington Mills, Inc. v. Congoleum Indus., Inc., 610 F.2d 1059, 1067 (3d Cir. 1979); Garrett \& Johnson, Antitrust Aspects of Geographical Restrictions in Patent Licensing Arrangements, 123 PLI Patent Antitrust 167, 172 (1980); Stern, supra note 63, at 583.

65. Deepsouth Packing Co. v. Laitram Corp., 406 U.S. 518, 531 (1972).

66. Garrett \& Johnson, supra note 64, at 169; A.B.A. ANTITrust SECTION Monograph, supra note 32, at 13-14; 35 U.S.C. $\$ 261$ (1982) ("patentee . . may . . . convey an exclusive right under his application for patent, or patents, to the whole or any specified part of the United States").

67. Garrett \& Johnson, supra note 64 , at 172; there is controversy about whether greater or less scrutiny applies to territorially restrictive trade secret licenses than to patent licenses; see infra Part IV.B.

68. Barton, Limitations on Territory, Field of Use, Quantity and Price in Know-how Agreements with Foreign Companies, 28 U. PitT. L. Rev. 195, 199 (1966); Kirkpatrick \& Mahinka, supra note 49, at 74245; see Antitrust Divison, U.S. Dep't of Justice, Antitrust Guide for International Operations, Cases E, F, at 30-32 (1977) [hereinafter DOJ Antitrust Guide for InTERnational. Operation]; 12 R. Milgrim, supra note 3 , at $\S 6.05[2]$, at 6-177. 
The most important of these factors is the commercial value of the licensed technology. ${ }^{69}$ If the know-how transferred under the license is unavailable from sources other than the licensor and is necessary to enable the licensee to enter a particular market, then the restraint on competition caused by the territorial restriction may be held to be "merely ancillary to the main purpose of a lawful contract." 70 Where the above-listed criteria are not satisfied, however, it may be inferred that the trade secret license was merely a subterfuge to effect a territorial division of the market among existing competitors in violation of section 1 of the Sherman Act. ${ }^{71}$ Additional factors such as the relative size of the parties, the number of competitors in the affected markets, whether the territorial restrictions are reciprocal, and the number of products affected by the restriction also may be considered in the determination of whether the restraint is ancillary. ${ }^{72}$

The ancillary restraint rule governing territorial restrictions has been attributed to Fowle v. Park ${ }^{73}$ and Dr. Miles Medical Co. v. John D. Parke E Sons, ${ }^{74}$ even though the former was decided before the Sherman Act was enacted, and the latter states, purely in dicta, that a license for a secret process may contain territorial restrictions without violating antitrust laws. In Fowle $v$. Park, the Supreme Court enforced an agreement to divide the country into regions where the seller and purchasers of a secret formula for a medicinal preparation had exclusive rights to manufacture and sell the remedy. The Court considered: (1) that the formula was secret; (2) that the purchasers had paid valuable consideration for their rights; (3) that useful discoveries should be rewarded; and (4) that the public should not care who sold it its medicine. ${ }^{75}$ The second and fourth elements of the Court's analysis would not be acceptable justifications for territorial restrictions in a case arising on similar facts today.

A good illustration of modern application of the ancillary restraint doctrine is provided by United States $v$. E.I. duPont deNemours $\mathcal{E}$ Co. ${ }^{76}$ A French firm, La Cellophane, granted duPont a license to manufacture and sell cellophane using its know-how; the parties agreed not to compete in each

69. A.B.A. Antitrust Section Monograph, supra note 32, at 22; Macdonald, supra note 1, at 375 (the intent of the parties is irrelevant).

70. United States v. Addyston Pipe \& Steel Co., 85 F. 271, 282 (6th Cir. 1898), modified, 175 U.S. 211 (1899); see DOJ Antitrust Guide for InTERnational Operation, supra note 68, at 25.

71. DOJ Antitrust Guide for International Operation, supra note 68, at 22; 12 R. Milgrim, supra note 3, at $\$ 6.05[2]$, at 6-177.

72. Adelman \& Brooks, Territorial Restraints in International Technology Agreements After Topco, 17 Antrtrust Bull. 763, 771 (1972) (A large licensor imposing territorial restrictions on a small licensee is suspect; reciprocal territorial restrictions are also highly suspect.); Stern, supra note 63, at 584 .

73. 191 U.S. 88 (1889).

74. 220 U.S. 373, 402 (1911), cited in United States v. E.I. duPont deNemours \& Co., 118 F. Supp. 41, 219 (D. Del. 1953), aff d, 351 U.S. 377 (1956), and Shin Nippon Koki Co. v. Irvin Indus., 186 U.S.P.Q. 296, 298 (N.Y. Sup. Ct. 1975).

75. Fowle, 131 U.S. at 97.

76. 118 F. Supp. 41 (D. Del. 1953), aff'd, 351 U.S. 377 (1956). 
other's territory. ${ }^{77}$ The Court rejected the government's charges of per se violation of the Sherman Act. Instead, the rule of reason was applied and the ancillary restraint doctrine was satisfied based on the following factual conclusions:

(1). La Cellophane developed a successful proven process for the commercial manufacture of cellophane. This process was secret, novel and of commercial value ....

(2). When duPont learned of cellophane, it entered upon the manufacture of the product. It was not then engaged in any business which would cause it to fear the competition of cellophane. Rather, it desired to diversify its business and take the business risk of entering this new field. La Cellophane, in turn, had no reason to fear duPont's competition for duPont had neither the necessary knowledge nor technical experience to compete in cellophane. No one else in the United States was making cellophane or seeking to get La Cellophane's process. It was not practicable to enter without having access to the French process ... ${ }^{78}$

The Court found that "neither party was motivated by anticompetitive considerations," and that it was only natural for the licensor to promise not to compete with the jointly created enterprise in its exclusive territory. ${ }^{79}$ The Court opined that the Sherman Act should not serve to discourage the introduction of new business into American markets. ${ }^{80}$ The parties may legitimately restrict competition that would not have existed but for the trade secret license. ${ }^{81}$

Subsequent cases have held that the critical issue in determining the ancillarity of territorial restrictions is the existence and extent of know-how possessed exclusively by the licensor. ${ }^{82}$ The court in $A$. Eं E. Plastik Pak Co. $v$. Monsanto $\mathrm{Co}^{83}$ viewed a non-competition clause as less burdensome than the competitive disability posed by not having access to the secret technology. ${ }^{84}$ Territorial restrictions were viewed in Shin Nippon Koki Co. v. Irvin Industries ${ }^{85}$ as an incentive to license and an assurance of an adequate reward for creative skill and diligence. ${ }^{86}$ The courts in both of these cases distinguished the "cartel cases": United States v. General Electric Co. (Lamp), ${ }^{87}$ United States $v$.

77. La Cellophane granted duPont exclusive rights under its cellophane patents and know-how in North and Central America and duPont granted La Cellophane exclusive rights in the rest of the world under any improvement patents and know-how. Id. at 58.

78. Id. at 218.

79. Id. at 219 .

80. Id.

81. Similarly, in Foundry Servs. v. Beneflux Corp., 110 F. Supp. 857 (S.D.N.Y), rev'd on other grounds, 206 F.2d 214 (2d Cir. 1953), the court upheld an agreement between the licensor and licensee not to sell outside their respective territories having found that they were not competitors, id. at 860 , and that their primary purpose was the transfer of know-how, id. at 861 .

82. A. \& E. Plastik Pak Co. v. Monsanto Co., 396 F.2d 710, 715 (9th Cir. 1968) (affirming denial of temporary injunction to stay arbitration pending judicial resolution of licensee's claim of violation of section 1, Sherman Act); Shin Nippon Koki Co. v. Irvin Indus., 186 U.S.P.Q. 296, 298-99 (N.Y. Sup. Ct. 1975) (also denying a stay of arbitration pending resolution of licensee's Sherman Act section I complaint).

83. 396 F.2d 710 (9th Cir. 1968).

84. Id. at 715 (quoting Macdonald, supra note 1 , at 354).

85. 186 U.S.P.Q. 296 (N.Y. Sup. Ct. 1975).

86. Id. at 298.

87. 82 F. Supp. 753 (D.N.J. 1949). 
Timken Roller Bearing Co., 88 and United States v. Imperial Chemical Industries. ${ }^{89}$ The Monsanto court stated:

In these cases complicated world-wide networks of cross-licensing agreements were struck down as subterfuges enabling the participants to divide markets and fix prices while avoiding antitrust laws. The courts found a lack of any true trade secrets or that what secrets existed were not sufficiently substantial to support restraints of such magnitude. The parties' intent, principally to restrain competition, was regarded as a critical factor. ${ }^{90}$

In General Electric (Lamp), the government challenged agreements by which General Electric exchanged patents and know-how with foreign companies while banning manufacture, sale, and sale for use in the United States by its foreign licensees and reserving foreign markets for themself. The court rejected General Electric's ancillary restraint defense because there was no clear evidence of what the alleged know-how consisted of, or whether it was embodied in all the products covered by the licenses. ${ }^{91}$ Furthermore, the evidence revealed that, were it not for the territorial restrictions, General Electric would have faced competition from its licensees. ${ }^{92}$ Similarly, the courts in Timken Roller Bearing and Imperial Chemical Industries found that the licensed know-how was not sufficiently secret or valuable to support the territorial division of markets arranged by the parties, and that the real purpose of the agreements was to restrain competition. ${ }^{93}$

The following arguments made in support of and opposition to recognizing an ancillarity defense in the cartel cases raised the issue of whether the same antitrust doctrine should apply to trade secret and patent license restrictions. In General Electric (Lamp), the government argued that a know-how licensor is entitled to less freedom than a patent licensor to impose license restrictions that restrain competition because of the statutory patent grant. ${ }^{94}$ On the other hand, the defendant in Timken Roller Bearing contended that a know-how licensor should be afforded greater liberty because no statute provided him or his licensee protection against public discovery. ${ }^{95}$ The differences between patent and trade secret protection, which may justify a different rule regarding territorial restrictions in licensing agreements, are discussed below in the context of a broader economic analysis of the rationale behind the antitrust limitations. ${ }^{96}$ In the next section, this note examines

88. 83 F. Supp. 284 (N.D. Ohio 1949), modified, 341 U.S. 593 (1951).

89. 100 F. Supp. 504 (S.D.N.Y. 1951). The court in Shin Nippon also distinguished two cases: United States v. National Lead Co., 63 F. Supp. 513 (S.D.N.Y. 1945), affd, 332 U.S. 319 (1947) (primarily involving patent licenses), and United States v. General Elec. Co., 80 F. Supp. 989 (S.D.N.Y. 1948) (also involving primarily patent licenses). Shin Nippon Koki Co. v. Irvin Indus., Inc., 186 U.S.P.Q. 296, 300 (N.Y. Sup. Ct. 1975).

90. A. \& E. Plastik Pak Co. v. Monsanto Co., 396 F.2d 710, 715 (9th Cir. 1968).

91. General Elec. Co. (Lamp), 82 F. Supp. at 846 .

92. Id. at 847.

93. United States v. Timken Roller Bearing Co., 83 F. Supp. 284, 313 (N.D. Ohio 1949); Imperial Chem. Indus., 100 F. Supp. at 528.

94. 82 F. Supp. at 846 .

95. 83 F. Supp. at 312 .

96. See infra text accompanying notes 126-30. 
another antitrust limitation on the freedom of trade secret owners to impose restrictive covenants on licensees.

\section{Tying Arrangements}

A tying arrangement is an agreement wherein sale of a product, called the tying product, is conditioned on concomitant purchase of another different product or service, called the tied product. ${ }^{97}$ Such arrangements may restrain competition in the tied product market by affording the party imposing the restriction leverage in the sale of the tied product that he would not otherwise enjoy. ${ }^{98}$ A sale conditioned on the purchase of another unrelated product is a contract in restraint of trade if the seller has "sufficient economic power with respect to the tying product to appreciably restrain free competition in the market for the tied product ....",99

A trade secret owner may impose a tying arrangement on his licensees by refusing to license his technology unless the licensee agrees to purchase certain inputs. A tying provision in a trade secret license can be sustained only if the licensor can convincingly show that the arrangement was necessary to protect the licensor's goodwill in the product of the licensed secret process and that technical product specifications would not suffice to protect that goodwill. ${ }^{100}$ The case law concerning tying arrangements both in trade secret licenses and in contracts for the sale of equipment embodying a trade secret uniformly embraces the following holding: Trade secret protection of the tying product is strong support for the legal conclusion that the seller has sufficient economic power in the tying product market to restrain competition in the tied product market. The cases also show, however, that certain legitimate business interests, such as protection of goodwill, safety considerations, and assurance of the success of a fledgling enterprise, can justify a tying arrangement and rebut a presumptive violation of section 1 of the Sherman Act.

The defendant in United States v. Jerrold Electronics Corporation ${ }^{101}$ developed equipment and know-how for the installation of community television antenna systems for communities remote from the broadcasting station. ${ }^{102}$ Jerrold Electronics agreed to sell and install antenna systems on the condition that the purchasing community accept a service contract. The Department of Justice charged Jerrold with a violation of section 1 of the Sherman Act. The court held that there were legitimate business reasons to justify the tying of

97. Northern Pacific Ry. v. United States, 356 U.S. 1, 5-6 (1958) (a tying arrangement may also be accomplished by requiring the purchaser to agree not to purchase the tied product from any other seller).

98. Id. at 6.

99. Id. (citing International Salt Co. v. United States, 332 U.S. 392 (1947)); see also Macdonald, supra note 1 , at 361 .

100. DOJ Antitrust Guide for International Operation, supra note 68, Case F, at 35.

101. 187 F. Supp. 545 (E.D. Pa. 1960), aff per curiam on other grounds, 365 U.S. 567 (1961).

102. Id at 549-52. The system involved construction of a large receiving tower at the highest point in the community and installation of a cable system on existing utility poles to amplify and transmit the signals. 
service contracts at the development stage of Jerrold's business, but that these reasons did not continue to justify the arrangement after the growth and establishment of the enterprise. ${ }^{103}$

Jerrold instituted its policy of mandatory purchasing of engineering services at a time when the antenna system had been installed in only a few communities, technical problems still needed to be solved, and the success of the newly developed system was highly uncertain. Thus, the following facts justified the competitive restraint: (1) the equipment was sensitive and unstable, requiring experienced engineers; (2) payment for the system was made contingent on its success; (3) the utility companies objected to having inexperienced workers install cable on their utility poles; and (4) Jerrold's reputation was at stake during the development period of the industry. ${ }^{104}$ The court found that there was no less restrictive alternative to a mandatory service contract to enable Jerrold to survive the "transitory disloyalties" of its initial customers. ${ }^{105}$

The defendant failed, however, to sustain its burden of showing the continued need for its policy. The court rejected Jerrold's contention that the tying arrangement was necessary to maintain profitability of sales: Jerrold argued that success of the system depended upon the head end equipment for which development costs were high; yet competitors could reap the benefit of Jerrold's ingenuity through the more profitable sale of amplifiers. ${ }^{106}$

A similar free-rider defense was rejected by the court in In re Data General Corp. Antitrust Litigation, ${ }^{107}$ where the defendant attempted to support the reasonableness of tying the purchase of hardware to its computer software licenses.108 Data General argued that competitors could take unfair advantage of the defendant's software research and development costs by selling hardware that was compatible with the defendant's software. The court held that Data General was required to resort to less restrictive alternatives, such as price restructuring, in order to recoup its investment in software development. ${ }^{109}$

103. Id. at 557-58. The same conclusion was reached with regard to Jerrold's policies of selling only complete equipment packages and retaining the rights to veto the purchaser's installation of additional equipment not purchased from Jerrold; however, an absolute prohibition of such purchase from other dealers was held invalid.

104. Id. at 556.

105. Id. at 557.

106. Id. at 560-61.

107. 490 F. Supp. 1089 (N.D. Cal. 1980) (cross-motions for summary judgment denied), 529 F. Supp. 801 (1981) (granting defendant Data General's motion for judgment non obstante veredicto and conditionally granting defendant's motion for a new trial), aff'd sub nom. Digidyne Corp. v. Data General Corp., 734 F.2d 1336 (9th Cir. 1984), cert. denied, 473 U.S. 908 (1985).

108. Data General's software license agreement prohibited the licensee from using the software with any central processing unit ("CPU") other than its Nova unit. Data General also required its software licensees to purchase a minimum amount of hardware or else pay a license surcharge and required its CPU purchasers to buy a minimum amount of memory equipinent. In re Data General Corp. Antitrust Litigation, 490 F. Supp. at 1098-99.

109. Id. at 1121-22; this holding was affirmed in Digidyne Corp. v. Data General Corp., 734 F.2d at 1343. The district court also rejected the defendant's asserted business justifications for the tying arrangement: customer dissatisfaction with incompatibility and the need to protect goodwill by 
Jerrold Electronics asserted the same business reasons for tying a service contract to the sale of antenna equipment in Jerrold Electronics Corp. v. Westcoast Broadcasting Co., ${ }^{110}$ namely the need to insure proper functioning of the system and protection of goodwill."11 The court found, however, that the real purpose of the tie was to enable Jerrold to control sales and to derive additional revenue from use of the system; these purposes were illegal. ${ }^{112}$ The court's conclusion was related to its finding that Jerrold had economic power in the market for antenna equipment because Jerrold was the only supplier for some components. ${ }^{113}$ Jerrold's policy enabled it to exclude any competitor from setting up a community antenna system. ${ }^{114}$ Thus, the Northern Pacific Railway test of an illegal tying arrangement was satisfied. ${ }^{115}$

Similarly, in In re Data General 16 the economic power of the defendant was a decisive issue. ${ }^{117}$ While a patent or copyright would give rise to a rebuttable presumption of sufficient power in the tying market to coerce purchase of the tied product, ${ }^{118}$ such a presumption has not been applied where the tying product is protected by a trade secret. ${ }^{119}$ However, evidence of a trade secret is probative of the uniqueness of a product and may form the basis for a jury conclusion that the defendant has sufficient market power to impose the tie. ${ }^{120}$ In contrast to a monopolization case under section 2 of the Sherman Act, the plaintiff is not required to demonstrate the defendant's power to control prices in the entire tying product market. Rather, in the case of a per se tying violation of section 1 , the plaintiff need only show that the defendant had market power sufficient to impose non-competitive prices or burdensome restrictions on an appreciable number of consumers. A reasonable jury conclusion that the defendant possessed market power may be based on evidence that the tying product, computer software, could not have been

minimizing service problems. In re Data General Corp. Antitrust Litigation, 490 F. Supp. at $1122-$ 23.

110. 341 F.2d 653 (9th Cir.), cert. denied, 382 U.S. 817 (1965).

111. Jerrold Elec. Corp., 341 F.2d at 663.

112. Id. at 663-64. Cf. Polytechnic Data Corp. v. Xerox Corp., 362 F. Supp. 1 (N.D. Ill. 1973) (where the court accepted seemingly insubstantial business justifications, namely the promotion of safety and assurance of the integrity and proper functioning of the defendant's equipment, to uphold Xerox's refusal to allow the plaintiff's copy controller keys to be installed on its leased copy machines).

113. Jerrold Elec. Corp., 341 F.2d at 661 .

114. Id. at 663 .

115. See supra notes $97-99$ and accompanying text.

116. 490 F. Supp. 1089, 1103 (N.D. Cal. 1980), affd sub nom., Digidyne Corp. v. Data General Corp., 734 F.2d 1336 (9th Cir. 1984), cert. denied, 473 U.S. 908 (1985).

117. On cross-motions for summary judgment, there was no genuine issue of material fact on other issues, and trial was restricted to the question of economic power. Id.

118. Id. at 1112, affd, 734 F.2d at 1344; United States v. Loew's, Inc., 373 U.S. 38 (1962); accord United States Steel Corp. v. Fortner Enter., Inc. (II), 429 U.S. 610, 619 n.12 (1977); Jack Winter, Inc. v. Koratron Co., Inc., 375 F. Supp. 1, 61 (N.D. Cal. 1974) (the requisite economic power may be presumed from the patent on the tying product).

119. In re Data General Corp. Antitrust Litigation, 490 F. Supp. at 1114; see Helein, Software Lockin and Antitrust Tying Arrangements: The Lessons of Data General, 5 CompuTER L.J. 329, 335 (1985).

120. In re Data General Corp. Antitrust Litigation, 490 F. Supp. at 1115. 
produced without misappropriating the defendant's trade secrets, infringing his copyright, or making a substantial investment in software development. ${ }^{121}$

In addition to the trade secret barrier and copyright protection, software consumer lock-in was relied on by the court in Digidyne Corp. v. Data General Corp. ${ }^{122}$ to support its conclusion that consumers were forced to purchase unwanted tied hardware: Original equipment manufacturers who purchased Data General's central processing unit ("CPU") and operations software developed applications software that functioned only with Data General's operations software. ${ }^{123}$ Such manufacturers were forced to purchase Data General's operations software and the tied CPU (or pay a license surcharge) for every system they sold. ${ }^{124}$ The software consumer lock-in theory has been criticized, however, as inconsistent with the realities of the software market. ${ }^{125}$

Thus, the trade secret owner is prohibited by section 1 of the Sherman Act from conditioning the licensing or sale of his trade secret on the purchase of unrelated products or services. Such a trade secret licensing restriction will be acceptable only if there are legitimate business reasons for the tie which exist throughout the period when the restriction is in effect, and if no less restrictive alternative is available to enable the trade secret owner to earn a profit from the use or sale of his trade secret.

Having examined the three most controversial trade secret licensing restrictions, an indefinite royalty term, a territorial restriction, and a tying provision, this note concludes with an economic analysis of the law in this area.

\section{$\mathrm{V}$}

\section{Economic Analysis}

The following section will explore the extent to which previous economic evaluations of the status of patent licensing restrictions under the antitrust laws apply to royalty term, tying arrangements, and territorial limitations in trade secret licenses. This analysis is preceded by a discussion of the extent to which the established antitrust restrictions on patent licensing contracts should generally be applied to trade secret licenses.

The Department of Justice has taken the position that stricter antitrust standards will be applied to trade secret license restrictions than are applied to the corresponding provisions in patent licenses. ${ }^{126}$ The justification for this attitude is that trade secrets lack the congressional mandate that gives patents special antitrust immunity. Stricter antitrust scrutiny of trade secret license restrictions has also been supported on the ground that trade secrets

121. Digidyne Corp. v. Data General Corp., 734 F.2d 1336, 1342 (9th Cir. 1984), cert. denied, 473 U.S. 908 (1985).

122. Id.

123. Id.

124. Id. at 1343 .

125. Helein, supra note 119 , at 339.

126. DOJ Antitrust Guide to International Operation, supra note 68, Case F, at 33-34. 
give the public no quid pro quo in the form of a substantial contribution to the body of useful industrial information, while patents add to the public's knowledge at the expiration of the patent. ${ }^{127}$ These arguments ignore the true economic purpose behind both patent and trade secret protection: to prevent the uncompensated appropriation of the valuable innovations of competing firms in order to provide a potential for return on their expenditures for research, development, and information gathering. Although trade secrets lack a congressional mandate, the Supreme Court recognized the contribution of state trade secret law to the stimulation of innovation in Kewanee Oil ${ }^{128}$ and Aronson. ${ }^{129}$ Furthermore, in contrast to the Department of Justice position, the lack of federally protected exclusive rights in the case of trade secrets actually lessens the possibility of an abuse of power when negotiating licensing agreements. ${ }^{130}$ The trade secret owner has a weaker bargaining position because he is unable to demonstrate the advantages of his information without disclosing the secret and because he cannot threaten an infringement suit if the potential licensee obtains and uses the industrial information by other legitimate means. Whereas a patent has presumptive validity and economic value, a trade secret has no presumed validity. However, once the value of a trade secret has been demonstrated, the antitrust analysis of license terms should be the same as is applied to patent licenses.

The test of validity of patent licensing restrictions under section 1 of the Sherman Act advocated by Professor Bowman of the Chicago school of antitrust critics is equally applicable to trade secret licenses. This test asks whether the restrictions imposed extend the patentee's market power beyond the proper scope of the patent. ${ }^{131}$ According to Professor Bowman, the scope of the patentee's exclusive rights is limited by the competitive superiority that the patented idea affords; therefore, it is impossible for the patent licensor to bargain for a broader monopoly without engaging in horizontal mergers, or restrictions that would also benefit the licensee. 132

If one accepts the premise that neither patents nor trade secrets necessarily confer a monopoly, the market power extension test or permissible licensing restrictions may be applied to trade secret licenses as well. The power conferred by either a patent or a trade secret depends on the

127. Stern, supra note 63 , at 590 .

128. Kewanee Oil Co. v. Bicron Corp., 416 U.S. 470, 485 (1974).

129. Aronson v. Quick Point Pencil Co., 440 U.S. 257, 262 (1979).

130. 12 R. MILGRIM, supra note 3, at § 6.05[2], at 6-186 to 6-187.

131. W. Bowman, Patent and antitrust Law 54 (1973).

132. Id. at 55, 64; see Baxter, Legal Restrictions on Exploitation of the Patent Monopoly: An Economic Analysis, 76 YALE L.J. 267, 313-14 (1966). Professor Baxter proposes a more limited test:

[A] patentee is entitled to extract monopoly income by restricting utilization of his invention, notwithstanding that utilization of other goods and services are [sic] consequently restricted, provided that in each case he confines the restriction to his invention as narrowly and specifically as the technology of his situation and the practicalities of his situation permit.

Id. at 313 . 
commercial value of the protected invention or information. Many patents are trivial innovations with many competing substitutes. ${ }^{133}$ Furthermore, patents for improvements or modifications of a patent invention may be worthless without access to the underlying patent. Therefore, the monopoly power held by either the patent or the trade secret proprietor must be measured not merely by the legal rights provided but more importantly by the comparative advantage of the protected invention or information. ${ }^{134}$

Professor Bowman argues that this comparative advantage gives the patent holder a fixed sum of monopoly power. If valid, this argument applies equally to a trade secret. Accordingly, any vertical restriction which the patent or trade secret owner imposes on his licensee is merely an effort to reap the full value of the protected innovation. ${ }^{135}$

Professor Kaplow of the Harvard school of antitrust analysis criticizes this view on grounds that it ignores the monopoly loss caused by restrictive license provisions. ${ }^{136}$ Instead, a ratio test is proposed: With respect to the ratio of the patentee's reward attributable to the license restriction to the resulting monopoly loss to society from permitting the restriction, the smaller the ratio, the greater is the likelihood that the restriction is anticompetitive. ${ }^{137}$ Application of this test requires a consideration of: (1) the extent to which monopoly loss is converted into profit for the patent owner without any accompanying misallocation of resources or inefficiency; (2) the portion of the monopoly profit that accrues to the patentee and the portion that is diverted to third parties who are undeserving of any reward for innovation; and (3) the degree to which firms are able to predict and appreciate the potential profits from a particular restrictive practice, so that permitting it under the antitrust laws increases the incentive to innovate. 138

Both the Harvard and Chicago school critics agree that patent law is needed to stimulate investment in inventive activity. Without the guarantee of exclusive rights to exploit the results of an investment in innovation, the innovator can capture only a small portion of the value of the innovation, probably not even a large enough return to cover his costs. ${ }^{139}$ The same rationale supports judicial recognition of trade secret licenses. Although investment in the development of ideas and information that is not patentable may not be as great as that required to invent a novel and non-obvious product or process, the market power afforded by enforcement of the trade secret laws is appropriately less. The antitrust limitations on trade secret licensing must be determined in view of the goal of ensuring that the

133. Kitch, Patents: Monopolies or Property Rights?, in 8 Research in Law and Economics 33 (J. Palmer guest ed. 1986).

134. See id. at 37.

135. W. Bowman, supra note 131 , at 55 .

136. Kaplow, The Patent-Antitrust Intersection: A Reappraisal, 97 Harv. L. Rev. 1813, 1851-52

(1984).

137. Id. at 1831-32.

138. Id. at $1835-39$.

139. Id. at 1823; Turner, The Patent System and Competitive Policy, 44 N.Y.U.L. REv. 450, 45 I (1969); W. Bowman, supra note 131, at 32; Baxter, supra note 132, at 268-69. 
developers of valuable information are able to recoup their capital investment. The net benefit to society should be considered by taking into account both the social value of an increase in inventive activity and the social cost of permitting imposition of restrictive provisions in license agreements. 140 This section now proceeds to a discussion of the antitrust validity of royalty term, tying, and territorial restrictions in trade secret licenses in view of the criticisms of legal doctrines in the patent licensing area.

\section{A. Tying Arrangements and Royalty Term}

In both the patent and trade secret licensing areas the courts have accepted the leverage theory behind holding tying arrangements illegal under either section 1 of the Sherman Act or section 3 of the Clayton Act. ${ }^{141}$ The Supreme Court held in Motion Picture Patents Co. v. Universal Film Manufacturing Co. ${ }^{142}$ that a license to use a patented film projector only with the patentee's unpatented film had the effect of "extending the power to the owner of the patent to fix the price to the public of the unpatented supplies as effectively as he may fix the price on the patented machine."'143 Mr. Justice Holmes, in dissent, advanced a counterargument that has been supported by the Chicago school critics:

The supposed contravention of public interest [posed by the tying arrangement] sometimes is stated as an attempt to extend the patent law to unpatented articles, which of course it is not, and more accurately as a possible domination to be established by such means. But the domination is one only to the extent of the desire for the ... [patented machine], and if the owner prefers to keep the [patented machine] unless you will buy his ... [unpatented supplies], I cannot see in allowing him the right to do so, anything more than an ordinary incident of ownership . . . ${ }^{144}$

Holmes' argument is based on the premise that the patentee has a fixed sum of monopoly power attributable to the competitive superiority of his patented invention and that this monopoly cannot be extended to markets for complementary products. If the patentee's goal is to maximize profits, then it is in his best interest to ensure that all complementary products are supplied to his licensees at a competitive price without output restrictions. Only if this condition exists will the licensee be able to use the patented machine or process efficiently and the licensor be able to maximize royalty revenue. ${ }^{145}$

140. See Kaplow, supra note 136, at 1828; cf. Turner, supra note 139, at 459, 463 (the validity of patent licensing restrictions under antitrust laws has insignificant effect on the patent reward and incentive to innovate because of extreme uncertainty with regard to any prospective return on investment in research and development).

141. Section 3 of the Clayton Act prohibits the conditioning of a sale or lease of goods upon the buyer's or lessee's agreement not to deal in the goods of a competitor of the seller or lessor, where such condition may substantially lessen competition or tend to create a monopoly. 15 U.S.C. $\$ 14$ (1982). This provision applies to a lessee's agreement to purchase supplies exclusively from the lessor, which has the same effect. United Shoe Mach. Corp. v. United States, 258 U.S. 451, 457 (1922).

142. 243 U.S. 502 (1917).

143. Id. at 517 (non-compliance with patent license restriction did not constitute patent infringement).

144. Id. at 520 (Holmes, J., dissenting) (emphasis added).

145. W. BoWMan, supra note 131 , at 72 . 
Otherwise a monopoly price charged for the tied product would reduce the demand for the tying patented product or process. ${ }^{146}$ Thus, Professor Bowman postulates that a tie-in results in no greater profit for the licensor than could be achieved by setting the optimum royalty; the tie-in determines the identity of the seller, but does not increase the price of the combined product nor restrict output of the tied product. ${ }^{147}$ The licensor of a patented machine may require the licensee to purchase supplies of unpatented complementary products from the licensor as a device to measure the licensee's use of the machine. ${ }^{148}$ In this way, the licensor may absorb some of the licensee's risk concerning the profitability of the machine over other technologies.

The fixed sum argument would also support a tying restriction in a trade secret license. The comparative advantage of a trade secret is determined not by the scope of patent claims, but by the relative secrecy, ease of reverse engineering, cost of development, and commercial utility of the trade secret. Following Professor Bowman's argument, the monopoly power offered by this comparative advantage is not improperly leveraged into markets not protected by the trade secret when a tying arrangement is imposed on licensees. The measuring device and risk-sharing functions of tying may be even more important in the trade secret license because of the uncertainty in value. Thus, Professor Bowman would not require Jerrold Electronics and Data General to defend their respective tying arrangements based on legitimate business justifications, because the revenue they derived from the tied service contracts and central processing units was attributable to the competitive advantage of Jerrold's antenna system and Data General's computer software, respectively.

Royalty term extension is also part of the leveraging fallacy according to Professor Bowman's perspective. ${ }^{149}$ He would disagree with the notion that a contractual obligation to pay royalties beyond the term of a patent is an attempt to tie unprotected use to protected use of a patented machine or process. ${ }^{150}$ Rather, the licensor and licensee have agreed on a price and method of payment that reflects the value of the patented idea to each of them. Applying Bowman's criticism to trade secret licensing, there is no leveraging involved when a licensee agrees to pay royalties to the trade secret

146. R. Posner, Antitrust Law: An Economic Perspective 173 (1976).

147. Bowman, Tying Arrangements and the Leverage Problem, 67 YALE L.J. 19, $21-23$ (1957). Tying arrangements have also been defended by Professor Bowman on grounds that they serve as a metering device to enable the licensor to measure the licensee's use of a patented machine. The greater the licensee's demand for supplies to be used with the machine, the greater the value of the machine to the licensee. Knowing this value enables the licensor to discriminate with respect to the royalty charged to his licensees, thereby increasing output. W. Bowman, supra note 131, at 55 .

148. W. Bowman, supra note 131 , at 55 .

149. Id. at 232.

150. Id. at 233. Bowman criticizes the majority opinion in Brulotte v. Thys, 379 U.S. $29,36 \mathrm{n} .1$ (1964) (agreeing with the dissent's point of view that a royalty contract longer than the patent term was in economic substance no different than charging 25 cents per load to use a washing machine for which the patent had expired). 
owner for a fixed term, regardless of subsequent disclosure. Accordingly, the royalty agreements in Brulotte and Aronson are not illegal per se.

Professor Kaplow criticizes the application of the fixed sum argument to tying arrangements as overly simplistic. He maintains that there is no clear distinction between the licensor's attempt to maximize profits and his attempt to extend monopoly power, and that the costs and benefits of restrictions must be assessed. ${ }^{151}$ According to Professor Kaplow, it may be feasible for a licensor to extend his monopoly power through a tying arrangement, because the tie may result in only small short-run losses from diminished demand for the tying product. ${ }^{152}$ Furthermore, licensors are motivated to impose tie-ins by the potential for effecting long-run changes in the market structure through foreclosure and the erection of entry barriers. ${ }^{153}$ Professor Kaplow teaches that antitrust law should not exclude the possibility that a tying arrangement will be imposed by a firm with a patent or trade secret monopoly. ${ }^{154}$

The courts in Jerrold Electronics and Data General implicitly accepted the plausibility of leverage theory by applying a per se rule against tying arrangements. ${ }^{155}$ Accordingly, Jerrold's tying of a service contract to the sale of community antenna systems may have had the effect of extending Jerrold's power into the service market. Although Jerrold had to forego equipment sales to purchasers who were willing to repair their own equipment, ${ }^{156}$ the company probably expected to make up for those losses with revenue from service contracts. Similarly, Data General attempted to use its market power in the software market to enter the hardware market. Yet neither court made an effort to analyze the probability of successful leveraging, or to weigh the benefits and burdens of permitting the tie-in. Professor Kaplow indicates that there are several factors overlooked by the fixed sum theory that may enable a tying arrangement to succeed in achieving monopoly extension. ${ }^{157}$ It is inconsistent with leverage theory to permit only those tying arrangements imposed by nascent industries without an analysis of the economic possibility of monopoly extension under the circumstances of the case. On the other hand, a per se rule against tying, with a limited exception for cases where the licensor can demonstrate necessity in the developmental stages of the firm, is a rule that gives greater certainty and avoids judicial inquiry into the degree of market power afforded by a trade secret. Furthermore, this exception should

151. Kaplow, Extension of Monopoly Power Through Leverage, 85 Colum. L. Rev. 515, 520-23 (1985). "Just as it matters where the terrorist leaves the stick of dynamite, it also matters how a firm chooses to exercise the power that it has." $I d$. at 525.

152. Id. at 526 .

153. Id. at 528-30. The possibility of formative entry barriers caused by trade secret monopoly is small in comparison to the potential barriers posed by a patent because of the difference in the extent of legal protection.

154. Id. at 555 .

155. The court in Jerrold Electronics made an exception to the per se rule for ties that had a legitimate business purpose, and the leveraging theory was not wholly rejected. 187 F. Supp. at 556.

156. Id. at 557 .

157. One factor, for example, is the inability of competitors and customers of the firm imposing a tie to resist the arrangement. Kaplow, supra note 151 , at 531-33. 
cover those situations in which the feasibility of market leverage is the least and the justification for permitting tying is the greatest.

\section{B. Territorial Restrictions}

An economic analysis of the appropriate antitrust limitations, on territorially exclusive patent licenses is also applicable to know-how licenses. ${ }^{158}$ While the trade secret licensor may impose an explicit restriction regarding the territories in which his licensee may exploit the licensed technology, the patent owner can achieve the same result by granting exclusive licenses under a number of national patents for the same invention. Professor Bowman's view of this practice is similar to his stance on tying arrangements. Territorially restrictive licensing, like other vertical restraints, is merely a means of maximizing the return on the investment in invention. The ability to exploit the differential advantages that the patented technology affords in different territories is inherent in the patent right. ${ }^{159}$

Critics of territorially restrictive licensing view the practice as posing a dangerous potential for effecting a cartel-like division of the market. ${ }^{160}$ Although the patent or trade secret owner receives his reward from royalties from his exclusive licensees as well as from exploitation of his innovation in his own exclusive territory, some of the reward is shifted to his licensees who enjoy monopoly profits in their respective territories. Thus, permitting a territorial division of the market defeats one of the purposes of protecting invention by rewarding those who have not contributed to the investment in innovation. ${ }^{161}$ It is recognized that the net negative effect on social welfare caused by territorial cartelization increases as the commercial value of the licensed technology decreases. ${ }^{162}$ Professors Turner and Baxter acknowledge that the licensor's ability to charge a different royalty in different territories has a negligible harmful effect on social welfare, ${ }^{163}$ or may even have the beneficial effect of increasing overall exploitation of the licensed technology. ${ }^{164}$ They propose a rule that once a patentee has granted a single territorial license, he must be compelled to grant similar licenses to all qualified applicants. ${ }^{165}$ Under this rule, the licensor would be provided with adequate incentive to innovate through royalties and through his ability to

158. In addition to the economic debate concerning the appropriate status of territorial patent licensing, a legal debate centers around the intent and effect of 35 U.S.C. $\$ 261$ (1982). See supra note 66; see also Baxter, supra note 132, at 349-52; Gibbons, Domestic Territorial Restrictions in Patent Transactions and the Antitrust Laws, 34 Geo. WASh. L. Rev. 893, 895-900 (1966); Wheeler, $A$ Reexamination of Antitrust Law and Exclusive Territorial Grants by Patentees, 119 U. PA. L. REv. 642, 643-50 (1971).

159. W. Bowman, supra note 131 , at 56.

160. Baxter, supra note 132, at 347; Turner, supra note 139, at 471 .

161. See Kaplow, supra note 136, at 1835-37.

162. Baxter, supra note 132 , at 347 . The courts have accepted this view in trade secret licensing cases; see, e.g., United States v. E.I. duPont deNemours \& Co., 118 F. Supp. 41 (D. Del. 1953).

163. Baxter, supra note 132 , at 347.

164. Turner, supra note 139 , at 471 .

165. Baxter, supra note 132, at 347; Turner, supra note 139 , at 474 . 
exploit the invention in his own exclusive territory. ${ }^{166}$ Turner would make an exception to the compulsory licensing rule for the case where, absent territorial exclusivity, neither the owner nor any potential licensee would exploit the technology. ${ }^{167}$

Another critic, Professor Gibbons, has taken a view of territorial restrictions more consistent with the courts' ancillary restraint doctrine. ${ }^{168}$ This view recognized that, under certain conditions, the benefits of licensing may outweigh the danger of cartelization. Professor Gibbons would permit territorial restrictions in patent licenses so long as: (1) the restriction is limited to a short development period; (2) the patented technology has a high degree of novelty; (3) the restraint covers only activities protected by the patent; (4) the licensee is a small firm in view of the capital requirements for the industry; (5) and only the making and use of the invention, and not the distribution of end products, is territorially restricted. Territorial licensing is justified under these conditions by the need to induce potential licensees to invest capital in the production and distribution of new technology, ${ }^{169}$ but only if no firm would accept a license without a territorial restriction. ${ }^{170}$

Professor Gibbons' proposal has been criticized on grounds that licensing may be prohibited where the parties need territorial restrictions in order to reduce the risks of developing and marketing a new product. ${ }^{171}$ Where the success and commercial value of new technology is relatively certain, capital is available to finance start-up costs; but where further research and development is necessary and ultimate success is uncertain, territorial restrictions are needed to entice the prospective licensee to undertake the investment risk. ${ }^{172}$ In this situation, mere protection against competition from other manufacturers and users in the same territory is an insufficient risk-taking incentive; the patent must promise potential rewards greater than the going rate of return. ${ }^{173}$ Professor Wheeler suggests a rule permitting the patentee to issue a single territorially exclusive license, so that the exploitation of new technology would be assured while the danger of cartelization would remain minimal. ${ }^{174}$

166. Baxter, supra note 132 , at 347 .

167. Turner, supra note 139, at 474; see also ABA Antitrust Section Monograph, supra note 32, at 12 .

168. Gibbons, supra note 158 , at 895 .

169. Id.

170. Id. at 901. Professor Gibbons' proposal is the basic approach taken by the European Economic Community, where firms have used the national patent laws to create market division; by issuing a regulation that permitted territorially restrictive licenses, the Community sought to "make patentees more willing to grant licenses and licensees more inclined to undertake the investment required to manufacture, use and put on the market a new product or to use a new process." Commission Regulation (EEC) No. 2349/84, preamble 912 (O.J. No. L 219, Aug. 16, 1984, at 15), 2 Common Mkt. Rep. $(\mathrm{CCH})$ I 2747, at 1958. The regulation prohibits a license provision requiring the parties to refuse to sell to users or resellers who would market licensed products in reserved territories. Id., If $2747 \mathrm{E}$, at 1958.

171. Wheeler, supra note 158 , at $651,657-62$.

172. Id. at 657-58.

173. Id. at 658 .

174. Id. at 665 . 
The single license rule should be applied in trade secret licensing cases involving territorial restrictions. By communicating secret know-how to a single licensee and granting him the exclusive right to exploit it in his territory, the trade secret owner restrains competition to no greater extent than if he had kept the information to himself. The parties should not be required to demonstrate that the subject matter of the license has significant commerical value so long as only a single territory is protected by the agreement, because commercial value is uncertain in those situations where the licensee's territorial exclusivity is needed most. However, once the trade secret owner attempts to divide the market to a greater extent by imposing a reciprocal restriction on the licensee-prohibiting him from exporting the products of a secret process-the agreement should be condemned per se under section 1 of the Sherman Act. ${ }^{175}$ Such reciprocal territorial restrictions cannot be justified by the need to protect fledgling firms that introduce new business into a territory. If the licensee is so weak that he needs exclusive territorial rights in order to survive the development period of the industry, then reciprocal protection against the licensee's exports is unreasonable. ${ }^{176}$ The Court in duPont (Cellophane) upheld reciprocal territorial restrictions based on a finding that duPont was "struggling to establish plain cellophane as a competing product in the flexible packaging market" at the time of the license agreement. ${ }^{177}$ This reasoning may have justified duPont's exclusive rights in North and Central America, but did not justify La Cellophane's exclusive rights in the rest of the world.

Furthermore, exclusive territorial rights for the licensee under trade secret licenses should be limited to a period needed for further research and development and to establish the new industry. This period can only be determined on a case-by-case basis in light of the licensed subject matter. When a single territorially exclusive license is granted by the licensor, it is not necessary for the courts to determine whether the licensed technology is novel, secret, or precisely defined in order for the agreement to pass antitrust scrutiny. The parties' own economic interests will ensure that these requirements are met. Applying this rule to trade secret licenses in order to permit a single exclusive territory, as Professor Wheeler has suggested for patent licenses, will avoid the necessity of judicial inquiry into whether technological innovations are substantial enough to support ancillary restraints and therefore lead to a just and economically reasonable application of the antitrust laws.

175. The Department of Justice has also taken the position that reciprocal territorial restraints in know-how licenses facilitate cartelization and permanent market division. DOJ ANTITRUST GUIDE FOR InTERnational Operation, supra note 68, Case F, at 34. An agreement by the trade secret licensee not to export products of the licensed know-how to other licensees' territories should be condemned for the same reasons.

176. Adelman \& Brooks, supra note 72 , at 769.

177. United States v. E.I. duPont deNemours \& Co., 118 F. Supp. at 220. 


\section{ConCLUSION}

Trade secrecy affords limited protection for industrial information; nevertheless, for certain types of innovations, the trade secret may be a useful and more desirable form of protection against uncompensated appropriation. A trade secret owner may agree to disclose his know-how and permit a party to utilize it in his business in exchange for royalty payments. Such agreements are enforceable even if the trade secret becomes known to competitors of the licensee. The trade secret licensor and licensee may also agree to restrict the territory in which industrial information may be exploited or to require that the licensee purchase certain complementary goods exclusively from the licensor. These restrictive clauses implicate the antitrust laws and may not always be enforced. Territorially restrictive licenses may be a subterfuge to divide product markets among competitors in violation of section 1 of the Sherman Act. A tying arrangement may be an attempt by the licensor to extend the market power afforded by the trade secret into complementary product markets. Both restrictions are generally condemned under the Sherman Act unless the territorial limitation is merely ancillary to an agreement to transfer substantial know-how or the tying requirement has compelling business purposes related to the establishment of a new industry exploiting the trade secret. By analogy to previous analyses of the antitrust limitations on similar restrictions in patent licenses, the objective of antitrust regulation of trade secret licensing should be to balance the need to secure an adequate reward for the developers of valuable commercial information against the tendency of license restrictions to tax social welfare through monopoly. With regard to tying arrangements, this balancing requires an evaluation of the market power of the trade secret and the ability of the licensor to leverage complementary product markets through foreclosure or erection of entry barriers. The antitrust policy regarding territorial restrictions in trade secret licenses should seek to weigh the risks of cartelization against the need to encourage the exploitation of valuable technology in new markets. 
